\section{Cultural filtrates of certain microbial isolates as an alternative to powdery mildew chemical control in cucumbers}

\author{
Aly S. Derbalah ${ }^{\dagger * *}$ and Gaber A. ElKot ${ }^{\dagger \dagger}$ \\ ${ }^{\dagger}$ Pesticides Department, Faculty of Agriculture, Kafr-El-Shiekh \\ University, 33516 Egypt \\ ${ }^{\dagger}$ Agricultural Botany Department, Faculty of Agriculture, Kafr-El- \\ Shiekh University 33516 Egypt
}

(Received April 2, 2011; Accepted April 25, 2011)

Powdery mildew caused by Sphaerotheca fuliginea (Schlecht. ex Fr.) Poll. is a major problem in cucumbers grown under greenhouse conditions. Culture filtrates of certain biocontrol agents (Epicoccum nigrum ES1, Epicoccum minitans ES2, Epicoccum sp ES3, Trichoderma harzianum ES4, Trichoderma viride ES5 and Bacillus pumilus ES6) were evaluated alone and in combination with penconazole against powdery mildew in cucumbers. The results showed that most of the culture filtrates of the tested microbial isolates in combination with the fungicide were more effective against powdery mildew than the fungicide alone at the recommended concentration level. The antifungal activity of the tested culture filtrates against powdery mildew was due to the presence of known antifungal compounds identified by GC-MS analysis. The results revealed that culture filtrates can be regarded as an effective control method for powdery mildew in cucumbers (C) Pesticide Science Society of Japan

Keywords: powdery mildew, culture filtrates, pathogen, cucumber.

\section{Introduction}

Powdery mildew caused by Sphaerotheca fuliginea (Schlecht. ex Fr.) Poll. is one of the most serious diseases in cucumbers $(\mathrm{Cu}$ cumis sativus L.), resulting in substantial yield losses, especially for greenhouse-grown cucumbers. ${ }^{1)}$ Cucurbits production in a greenhouse is dependent on the intensive use of fungicides to control powdery mildew; however, fungicide residues have become a major issue, resulting in legislative action to limit and regulate pesticide use. Indeed, the maximum legal limits for pesticide residues on food [maximum residue level (MRL)] have been mandated in all countries. ${ }^{2)}$

As a result of this change in public attitudes towards the use of

\footnotetext{
* To whom correspondence should be addressed. E-mail: aliderbalah@yahoo.com Published online June 11, 2011 (C) Pesticide Science Society of Japan
}

chemicals and the development of pathogen strains resistant to fungicides, new alternatives are required. Several alternative control agents, i.e. salts, plant extracts, culture filtrate of biocontrol agents (BCAs) and mineral oils alone or in combination, have been tested against powdery mildews on different crops. ${ }^{3-7)}$ The use of culture filtrates of BCAs and plant extracts are a practice that has gained increasing acceptance as the cost of developing new active ingredients is still much higher than the cost of developing new adjuvants.

Therefore, this study aimed to evaluate the efficiency of culture filtrates of certain bio-agents for controlling powdery mildew in cucumbers, to minimize the recommended dose of the chemical fungicide used to control powdery mildew in cucumbers by mixing fungicide at low doses with the culture filtrate of certain biocontrol agents and to identify the chemical compounds responsible for the possible biological activity of the culture filtrates of bio-control agents against powdery mildew in cucumbers.

\section{Materials and Methods}

\section{Biocontrol agents}

The biocontrol agents (BCAs) used in this investigation were Epicoccum nigrum ES1, Epicoccum minitans ES2, Epicoccum sp. ES3, Trichoderma harzianum ES4, Trichoderma viride ES5 and Bacillus pumilus ES6. All tested microorganisms were isolated from cucurbits plants and identified according the method described by El-Kot and Hegazi. ${ }^{8)}$ These microbes were selected to evaluate the efficiency of their culture filtrates against powdery mildew by a screening test with other bacterial and fungal microbial isolates under greenhouse conditions (unpublished data). The fungal and bacterial culture filtrates were prepared according to the method described by El-Bogdady. ${ }^{9}$

2. Control of powdery mildew disease on cucumbers under greenhouse conditions

This study was carried out at in a greenhouse at the Faculty of Agriculture, Kafr El-Sheikh University, using the randomized complete block design with three replicates. Cucumber seeds were sown in rows of $1 \mathrm{~m}$ width and $50 \mathrm{~cm}$ long. Plants were sprayed with 25 treatments (penconazole fungicide and culture filtrates of the tested BCAs alone and their combinations) at 10day intervals. Because the natural presence of this pathogen varies widely on cucumber plants, evaluation of the tested treatments efficacy is inaccurate; therefore, artificial inoculation with powdery mildew pathogen was performed to stabilize the pathogen population in all treatments. Artificial inoculation was carried out by gently shaking leaves heavily infected with powdery mildew over the plants until the leave surface was fully covered with powdery mildew spores. The heavily infected cucumber leaves that used as a source for artificial inoculation with powdery mildew were obtained from cucumber plants grown in the greenhouse used in this study; however, these plants were not the treated cucumber plants in this study. As artificial inoculation 
Table 1. Effect of penconazole and culture filtrates of the control agents alone and in combination on powdery mildew of cucumbers under greenhouse conditions during the first season

\begin{tabular}{|c|c|c|c|c|c|}
\hline \multirow{2}{*}{$\begin{array}{c}\text { Treatments } \\
\text { Control agents }\end{array}$} & \multirow[b]{2}{*}{ Culture filtrate (\%) } & \multirow[b]{2}{*}{ Penconazole $(\%)^{a)}$} & \multicolumn{2}{|c|}{$\%$ Disease severity } & \multirow{2}{*}{$\begin{array}{l}\% \text { Disease inhibition } \\
\quad(\text { corrected })^{b)}\end{array}$} \\
\hline & & & $\begin{array}{l}10 \text { days after } \\
\text { inoculation }\end{array}$ & $\begin{array}{c}40 \text { days after } \\
\text { starting application }\end{array}$ & \\
\hline \multirow[t]{4}{*}{ Epicoccum sp. ES3 } & 100 & 0 & 87.4 & 51.7 & $76 \mathrm{ij}$ \\
\hline & 75 & 25 & 79.6 & 11.8 & $94 \mathrm{k}$ \\
\hline & 50 & 50 & 54.4 & 2.6 & $98 \mathrm{a}$ \\
\hline & 25 & 75 & 66.7 & 1.4 & $99 \mathrm{a}$ \\
\hline \multirow[t]{4}{*}{ E. nigrum $\mathrm{ES} 1$} & 100 & 0 & 66.7 & 8.2 & $95 \mathrm{abcd}$ \\
\hline & 75 & 25 & 51.7 & 10.2 & $92 \mathrm{de}$ \\
\hline & 50 & 50 & 10.2 & 5.4 & $78 \mathrm{ij}$ \\
\hline & 25 & 75 & 89.8 & 68.8 & $68 \mathrm{k}$ \\
\hline \multirow[t]{4}{*}{ E. minitans $\mathrm{ES} 2$} & 100 & 0 & 42.1 & 11.8 & $88 \mathrm{ef}$ \\
\hline & 75 & 25 & 59.8 & 20.4 & $86 \mathrm{f}$ \\
\hline & 50 & 50 & 76.3 & 39.8 & $78 \mathrm{ij}$ \\
\hline & 25 & 75 & 23.7 & 20.4 & 641 \\
\hline \multirow[t]{4}{*}{ T. viride ES5 } & 100 & 0 & 46.7 & 16.6 & $85 \mathrm{f}$ \\
\hline & 75 & 25 & 62.5 & 20.4 & $87 \mathrm{f}$ \\
\hline & 50 & 50 & 89.0 & 13.4 & $94 \mathrm{~cd}$ \\
\hline & 25 & 75 & 68.8 & 10.2 & $94 \mathrm{~cd}$ \\
\hline \multirow[t]{4}{*}{ T. harzianum ES4 } & 100 & 0 & 15.5 & 16.6 & $75 \mathrm{j}$ \\
\hline & 75 & 25 & 39.8 & 20.4 & $76 \mathrm{ij}$ \\
\hline & 50 & 50 & 66.7 & 2.6 & $87 \mathrm{f}$ \\
\hline & 25 & 75 & 54.5 & 16.6 & $98 \mathrm{abc}$ \\
\hline \multirow[t]{4}{*}{ B. pumilus ES6 } & 100 & 0 & 39.8 & 16.6 & $83 \mathrm{gh}$ \\
\hline & 75 & 25 & 46.7 & 6.4 & $94 \mathrm{bcd}$ \\
\hline & 50 & 50 & 27.0 & 3.3 & 95 abcd \\
\hline & 25 & 75 & 39.8 & 1.4 & $99 \mathrm{ab}$ \\
\hline Penconazole only & 0.00 & 100 & 54.4 & 27.0 & 80 hi \\
\hline Control (Water) & 0.00 & 0.00 & 39.8 & 96.5 & $0.00 \mathrm{~m}$ \\
\hline
\end{tabular}

${ }^{a)}$ Penconazole was provided at the recommended concentration by the manufacturer ( $250 \mathrm{~mL}$ ai/hectare). ${ }^{b)}$ a, b, c, d, e, f, g, h, i, j, k, 1 and $\mathrm{m}$ indicate the significance and non-significance between means using Duncan multiple range test.

with powdery mildew pathogen was performed using the same plant pathogen from the same greenhouse, differences in the pathogenicity of the naturally present and artificial powdery mildew were not expected. The different treatments used to control powdery mildew in this study were applied $6 \mathrm{hr}$ before artificial inoculation.

\section{Disease assessments}

Disease severity was assessed 10 days after the first inoculation (initial disease severity) and then three times at 10-day intervals; thus, the last assessment was 40 days after application (final disease severity). According to the method described by McGrath et al. ${ }^{10)}$ powdery mildew disease severity was estimated by counting visible sporulating mildew colonies on both adaxial and abaxial surfaces per leaf. Five old leaves per plant were examined for five plants in each plot (i.e. 25 leaves/treatment). Fully expanded leaves from the middle and upper thirds of a plant were also assessed and data from all three age classes of leaves were 
Table 2. Effect of penconazole and culture filtrates of the control agents alone and in combination on powdery mildew of cucumbers under greenhouse conditions during the second season

\begin{tabular}{|c|c|c|c|c|c|}
\hline \multirow{2}{*}{$\begin{array}{c}\text { Treatments } \\
\text { Control agents }\end{array}$} & \multirow[b]{2}{*}{ Culture filtrate $(\%)$} & \multirow[b]{2}{*}{ Penconazole $(\%)^{a)}$} & \multicolumn{2}{|c|}{$\%$ Disease severity } & \multirow{2}{*}{$\begin{array}{l}\text { \% Disease inhibition } \\
\quad(\text { corrected })^{b)}\end{array}$} \\
\hline & & & $\begin{array}{l}10 \text { days after } \\
\text { inoculation }\end{array}$ & $\begin{array}{c}40 \text { days after } \\
\text { starting application }\end{array}$ & \\
\hline \multirow[t]{4}{*}{ Epicoccum sp. ES3 } & 100 & 0 & 62.5 & 23.7 & $82 \mathrm{fgh}$ \\
\hline & 75 & 25 & 85.5 & 20.4 & $89 c$ \\
\hline & 50 & 50 & 78.0 & 17.7 & $89 c$ \\
\hline & 25 & 75 & 79.6 & 12.6 & $92 \mathrm{ab}$ \\
\hline \multirow[t]{4}{*}{ E. nigrum ES1 } & 100 & 0 & 73 & 10.2 & $94 \mathrm{a}$ \\
\hline & 75 & 25 & 62.5 & 18.8 & $86 \mathrm{~d}$ \\
\hline & 50 & 50 & 57.1 & 33.3 & $73 \mathrm{k}$ \\
\hline & 25 & 75 & 46.7 & 29.1 & 711 \\
\hline \multirow[t]{4}{*}{ E. minitans $\mathrm{ES} 2$} & 100 & 0 & 70.9 & 23.7 & $85 \mathrm{de}$ \\
\hline & 75 & 25 & 59.8 & 25.4 & 81 ghi \\
\hline & 50 & 50 & 59.8 & 27 & $79 \mathrm{j}$ \\
\hline & 25 & 75 & 33.3 & 23.7 & $67 \mathrm{~m}$ \\
\hline \multirow[t]{4}{*}{ T. viride ES5 } & 100 & 0 & 64.6 & 23.7 & $80 \mathrm{ij}$ \\
\hline & 75 & 25 & 54.5 & 20.4 & $83 \mathrm{fg}$ \\
\hline & 50 & 50 & 76.3 & 14.5 & $91 \mathrm{~b}$ \\
\hline & 25 & 75 & 87.4 & 15.5 & $92 \mathrm{~b}$ \\
\hline \multirow[t]{4}{*}{ T. harzianum ES4 } & 100 & 0 & 39.8 & 29.1 & $66 \mathrm{~m}$ \\
\hline & 75 & 25 & 51.7 & 29.1 & $73 \mathrm{k}$ \\
\hline & 50 & 50 & 66.7 & 22 & $85 \mathrm{de}$ \\
\hline & 25 & 75 & 62.5 & 15.5 & $89 c$ \\
\hline \multirow[t]{4}{*}{ B. pumilus ES6 } & 100 & 0 & 57.1 & 31.2 & $75 \mathrm{k}$ \\
\hline & 75 & 25 & 66.7 & 23.7 & 81 ghi \\
\hline & 50 & 50 & 39.8 & 14.5 & $831 \mathrm{ef}$ \\
\hline & 25 & 75 & 64.6 & 20.4 & $85 \mathrm{~d}$ \\
\hline Penconazole only & 0 & 100 & 57.1 & 23.7 & $81 \mathrm{hi}$ \\
\hline Control (Water) & 0 & 0 & 44.4 & 95.8 & $0.00 \mathrm{~b}$ \\
\hline
\end{tabular}

a) Penconazole was provided at the recommended concentration by the manufacturer $\left(250 \mathrm{~mL}\right.$ ai/hectare). ${ }^{b)}$ a, b, c, d, e, f, g, h, i, j, k, 1 and $\mathrm{m}$ indicate the significance and non-significance between means using Duncan multiple range test.

averaged. As the initial disease severity varied under greenhouse conditions even though the pathogen spore density was approximately the same, it was worth calculating the disease inhibition (DI\%) to evaluate the real comparable efficacy of treatments, as shown by Eq. (1).

$$
\mathrm{DI} \%=\mathrm{A}-\mathrm{B} / \mathrm{A} \times 100
$$

Where A denotes the corrected final disease severity of treatment, and B denotes the final disease severity of treatment, respectively. The corrected final disease severity (A) was calculated as the product of corrected disease severity, as shown by Eq. (2) according to the method described by Kamel. ${ }^{11)}$

$$
\text { Corrected disease severity }=\mathrm{L} / \mathrm{M} \times \mathrm{N}
$$

Where $\mathrm{L}$ is the initial disease severity of a treatment, $\mathrm{M}$ is the initial disease severity of the control and $\mathrm{N}$ is the final disease severity of the control. 
Table 3. Main constituents of E. nigrum ES1 culture filtrate identified using GC-MS analysis

\begin{tabular}{clcr}
\hline No. & \multicolumn{1}{c}{ Identified compounds } & $\begin{array}{c}\text { Retention } \\
\text { time (min) }\end{array}$ & \% Area ${ }^{a)}$ \\
\hline 1 & 2-Butyl ester of benzoic acid & 7.56 & 58.32 \\
2 & 2-Amino- 6-methyl-benzoic acid & 8.20 & 1.01 \\
3 & 6-Methyl-2-phenylindole & 11.99 & 23.99 \\
4 & 2-Pentyl ester of benzoic acid & 13.72 & 2.99 \\
5 & Carvacrol methyl ether & 13.92 & 7.48 \\
6 & Dimethylcyclosiloxane & 17.72 & 1.78 \\
7 & 5-Methyl-2-phenylindolizine & 17.30 & 4.29 \\
8 & 2-Butylbenzothiazole & 17.72 & 3.49 \\
9 & (E)-2-Octenal & 17.87 & 6.77 \\
\hline
\end{tabular}

a) $\%$ Area $=$ the percentage of each component in the analyzed extract depending on its peak area.

\section{Chemical composition of bacterial and fungal culture fil- trates}

The most effective fungal (E. nigrum ES1) and bacterial ( $B$. pumilus ES6) culture filtrates were selected for analysis to identify the active components in these culture filtrates. GC/MS analysis was conducted according to the method described by Mahboubi and Haghi. ${ }^{12)}$

\section{Results}

1. Effect of penconazole and B. pumilus ES6 culture filtrate alone and in combination on powdery mildew during the tested seasons

The results in Tables 1 and 2 shows that penconazole and the culture filtrate of $B$. pumilus ES6 significantly reduced the disease severity of powdery mildew in cucumbers relative to the control treatment either alone or in combination in both tested seasons. The efficacy of the bacterial culture filtrate mixed with the fungicide was higher than the bacterial culture filtrate and the fungicide alone in both tested seasons. The results in Table 2 revealed that mixing the bacterial culture filtrate with the fungicide at 25 to $75 \%$ proportion induced the highest effectiveness against powdery mildew compared to other mixed percentages in both tested seasons.

2. Effect of penconazole and culture filtrates of the fungal bio-agents alone and in combination on powdery mildew during the tested seasons

The results in Tables 1 and 2 shows that the fungicide and the culture filtrates of the tested fungal isolates either alone or in combination significantly reduced the disease severity of powdery mildew in cucumbers relative to the control treatment in both tested seasons. The results also showed that the use of $E$. nigrum ES1, T. viride ES5 and E. minitans ES2 culture filtrates alone gave higher effectiveness than the use of fungicide alone in both tested seasons. The culture filtrate of E. nigrum ES1, isolate
Table 4. Main constituents of B. pumilus ES 6 culture filtrate identified using GC-MS analysis

\begin{tabular}{llcc}
\hline No. & \multicolumn{1}{c}{ Identified compounds } & $\begin{array}{c}\text { Retention } \\
\text { time (min) }\end{array}$ \\
\hline 1 & 2,4-Decadienal & \\
\hline 2 & Hexadecanoic acid & 7.55 & 31.83 \\
3 & Diethyl phthalate & 12 & 46.65 \\
4 & Oleic acid & 13.72 & 2.05 \\
5 & 3,4-Dimethyl-5-hexen-3-ol & 13.92 & 2.87 \\
6 & 4-Hexen-1-yl ester of propionic acid & 17.12 & 1.86 \\
7 & 1H-Imidazole-1-ethanol & 17.72 & 4.29 \\
8 & (E)-2-Octenal & 17.87 & 6.77 \\
\hline
\end{tabular}

a) $\%$ Area $=$ the percentage of each component in the analyzed extract depending on its peak area.

was the most effective treatment in both tested seasons. Mixing the culture filtrate of E. nigrum ES1, or E. minitans ES2 with the fungicide decreased its efficacy compared with its use alone; however, the combination of the culture filtrates of these two bioagents increased their efficacy relative to the fungicide alone in both tested seasons. Mixing the T. viride ES5, T. harzianum ES4 and Epicoccum sp. ES3 culture filtrates with the fungicide increased its efficacy against powdery mildew in both tested seasons.

\section{Composition of the fungal and bacterial culture filtrates}

Nine compounds were identified from the most effective fungal (Epicoccum nigrum ES1) culture filtrate while eight compounds were identified from the bacterial (B. pumilus ES6) culture filtrate with different percentages: 2,4-decadienal, hexadecanoic acid, diethyl phthalate, oleic acid, 3,4-dimethyl-5-hexen-3-ol, 4-hexen-1yl ester of propionic acid, $1 H$-imidazole-1-ethanol, 2-butyl ester of benzoic acid, 2-amino-6-methyl-benzoic acid, 6-methyl-2phenylindole, 2-pentyl ester of benzoic acid, carvacrol methyl ether, dimethylcyclosiloxane, 5-methyl-2-phenylindolizine, 2butylbenothiazole and $(E)$-2-octenal as shown in Tables 3 and 4. The identified compounds belonged to aldehydes, esters, alcohols and fatty acids.

\section{Discussion}

The present study implied that the culture filtrates of the tested fungal and bacterial biocontrol agents showed high effectiveness against powdery mildew pathogen in cucumbers under greenhouse conditions and this is in agreement with the findings of many researchers who reported that the compounds produced by antagonistic fungi and bacteria have potential antifungal activities against plant pathogens. ${ }^{13-17)}$ Previously, many researchers found that Bacillus sp. and their nonvolatile compounds made considerable contributions to the control of plant diseases. ${ }^{18-19)}$ This study also indicated that the use of culture filtrates of the microbial isolates mixed with the fungicide improved their efficacy against the 
powdery mildew pathogen compared to using it alone. ${ }^{20-21)}$ Furthermore, the improvement of fungicide efficacy by mixing with the microbial culture filtrates has been reported but not on powdery mildew of cucumbers.

Among these compounds identified by GC-MS analysis from the fungal (E. nigrum ES1) and bacterial (B. pumilus ES6) culture filtrates, some compounds such as: 2-butyl ester of benzoic acid, carvacrol methyl ether, 2-butylbenothiazole, 6-methyl-2phenylindole, hexadecanoic acid and oleic acid appeared to account for a larger percentages. The antifungal activity of the fungal and bacterial culture filtrates against powdery mildew pathogen may be due to the presence of these fatty acids and their derivatives. ${ }^{22-26)}$ Although the antimicrobial activity of the culture filtrates is attributed mainly to their major compounds, the synergistic or antagonistic effect of one compound in minor percentage in the mixture has to be considered when assessing antifungal activity. $^{27)}$

\section{Conclusions}

The culture filtrates of the tested BCAs can be regarded as an effective control method against powdery mildew. The culture filtrates of these biocontrol agents contained different biologically active compounds. The combination of fungicide with these culture filtrates is possible and reduces the fungicide amount applied.

\section{References}

1) J. M. Feng, H. Y. Zhang, N. L. Chen, Y. J. Wang: Chin. Agric. Sci. Bull. 24, 368-372 (2008).

2) D. J. Calvert and C. B. Huffaker: Entomophaga 19, 361-369 (1974).

3) R. R. Bélanger and M. Benyagoub: Can. J. Plant Pathol. 19, 310-314 (1997)

4) F. Daayf, A. Schmitt and R. R. Bélanger: Sci. Cult. 39, 556-558 (1997).

5) S. P. Falk, D. M. Gadoury, P. Cortesi, R. C. Pearson and R. C. Seem: Phytopathology 85, 794-800 (1995).

6) R. K. Horst, S. O. Kawamoto and L. L. Porter: Plant Dis. 76, 247-251(1992).

7) R. Reuveni, V. Agapov, M. Reuveni and M. Raviv: J. Phy- topathol. 142, 331-337 (1994).

8) G. A. N. El-Kot and M. A. Hegazi: Alex. J. Agric. Res. 53, 219-230 (2008)

9) M. M. E. El-bogdady: Integrated postharvest diseases management of certain pome fruits. Ph D. Thesis, Faculty Agriculture Al-Azhar University, p. 55 (1993).

10) M. T. McGrath, H. Staniszewska and N. Shishko: Plant Dis. 80, 697-703 (1996).

11) S. M. H. Kamel: Antogonistic effects of some microbial inhabitants on phylloplane of squash plants toward Sphaerotheca fuliginea. M Sc. Thesis, Faculty Agriculture Tanta University, p. 94 (2003).

12) M. Mahboubi and G. Haghi: J. Ethnopharmacol. 199, 325-327 (2008).

13) D. W. G. Fernando, R. Ramarathnama, A.S. Krishnamoorthy and S. C. Savchuk: Soil Biol. Biochem. 37, 955-964 (2005).

14) M. Kai, U. Effmert, G. Berg and B. Piechulla: Arch. Microbiol. 157, 351-360 (2006).

15) C. S. Zou, M. H. Mo, Y. Q. Gu, J. P. Zhou and K. Q. Zhang: Soil Biol. Biochem. 39, 2371-2379 (2007).

16) J. Mercier and D. C. Manker: Crop Prot. 24, 355-362 (2005).

17) M. Koitabashi: J. Gen. Plant Pathol. 71, 280-284 (2005).

18) S. A. Algam, G. L. Xie, B. Li, J. Coosemans and B. Liu: J. Zhejiang Univ. 30, 603-610 (2004).

19) X. W. Hou, S. M. Boyetchko, M. Brkic, D. Olson, A. Ross and D. Hegedus: Appl. Microbiol. Biotechnol. 72, 644-653 (2006).

20) O. Fan and S. Tian: Postharvest Biol. Technol. 21, 257-358 (2001).

21) S. S. Yoshida, T. Hiradate, K. Tsukamoto and A. Shirata: Biol. Control 91, 2181-187 (2001).

22) W. Dale, L. Raynor, A. Mitchell, R. Walker and K. Wallker: Mycopathologia 157, 87-90 (2004).

23) W. Pritee, M. Rai, S. K. Deshmukh and M. C. T. Durate: Afr. J. Biotechnol. 6, 1592-1596 (2007).

24) A. Ultee, M. H. J. Bennik and R. Moezelaar: Appl. Environ. Microbiol. 68, 1561-1568 (2002).

$25)$ L. G. Goncalvesa, J. M. F. Nogueira, O. Matos and R. B. De Sous: J. Photoch. Photobiol. B: Biol. 70, 51-54 (2003).

26) F. Neri, M. Mari, S. Brigati and P. Bertolini: Postharvest Biol. Technol. 51, 425-430 (2009).

27) C. Y. Ragas, J. G. Hofilena and J. A. Rideout: J. Nat. Prod. 65, 1107 (2002). 